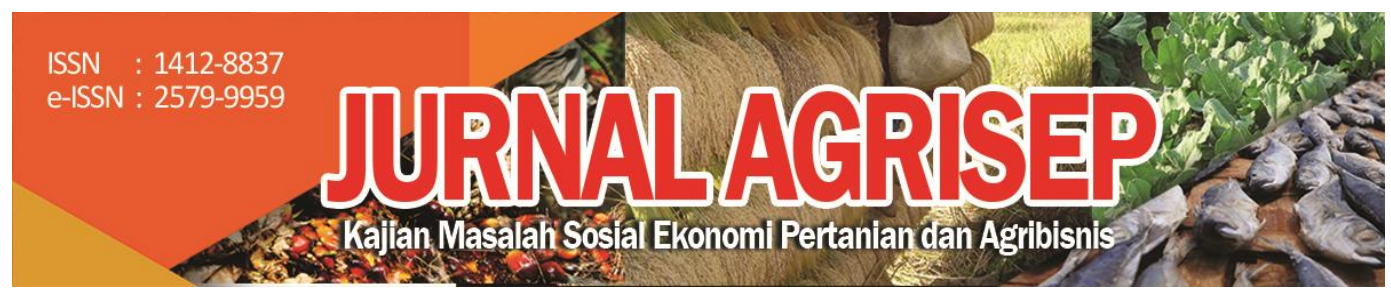

DOI: 10.31186/jagrisep.19.1.177-190

\title{
PERAN MOSAL SOSIAL KELOMPOK SADAR WISATA DALAM \\ MENGEMBANGKAN DESA WISATA KOPI DI DESA KUMPAI BATU ATAS, KABUPATEN KOTAWARINGIN BARAT, PROVINSI KALIMANTAN TENGAH \\ The Role Of Capital Sosial Group In Developing Coffee Tourist Vallage \\ In Kumpai Batu Atas Village, West Kotawaringin Barat District, Central Kalimnantan Province
}

\author{
Brian L. Djumaty $\square$; Nina Putri Hayam Dey²) \\ 1)Jurusan Studi Pembangunan Fakultas Ekonomi Universitas Antakusuma \\ 2) Jurusan Studi Pembangunan Fakultas Ekonomi Universitas Antakusuma \\ Email: brian.djumaty@gmail.com
}

\begin{abstract}
Indonesia is one of the world's tourist destination countries because it has various types of interesting tourist objects that are spread from Sabang to Marauke. The development of tourism in Indonesia has a very significant impact on the country's foreign exchange income. According to a report from parliament an increase in income to the country's foreign exchange reached USD 15 million or as much as 203 trillion. From this increase the tourism sector came in second place after crude palm oil was in the first position in contributing to the largest trade division. This positive trend has a positive contribution because it has an impact on expanding employment, improving the community's economy, spurring regional development, aspecially in areas with potential tourist attraction. One of them is Kotawaringin Barat Regency which has a veriety of tourism potential including Tanjung Putting National Park (TNTP), Coffee Tourism Village in Kumpai Batu Atas Village and others. Before the development of a coffee tourism village, coffee farmers in the village experienced various problems and constraints due to low process (20 thousand rupiah/kilo) and minimal acces to market. This is what causes most people to turn to other communities. However, in 2017 coffee began to be developed by the local community towards the coffee tourism village so the price has increased to 300 thousand rupiah per kilo. In addition there has been an. increase in foreign and domestic tourist visitors. This study aims to determine and anayze the role of social capital (bonding, bridging, networking) tourism awareness group (POKDARWIS) in developing coffee tourism village in Kumpai Batu Atas village,
\end{abstract}


Kotawaringin Barat Regency. This research uses descriptive qualitative methodology. By using snowball sampling techniques in determining informants. The results showed that stakeholders ranging from the private sector, government, media, NGOs and others had given attention to develop coffee tourism such as providing assistance, aquipment, finance, training and assistance. This enthusiasm was not matched by the function and role of the tourism awareness agroup. Due to lack of communication between members so this group has no activities. Even so one of the actors (memners of Pokdarwis) is committed to developing a coffee tourism village so that it can be well-known and have an impact on coffee farmers in the village of Kumpai Batu Atas.

Kata Kunci : Modal Sosial, Pariwisata, Kopi Liberika, Kelompok Sadar Wisata

\section{ABSTRAK}

Indonesia merupakan salah satu negara tujuan wisata dunia karena memiliki berbagai jenis objek wisata yang menarik yang tersebar dari sabang sampai merauke. Perkembangan pariwisata di Indonesia membawa dampak yang sangat siknifikan bagi pemasukan devisa negara. Menurut laporan dari parlemen peningkatan pemasukan terhadap devisa Negara mencapai USD 15 juta atau sebesar 203 Triliun. Dari peningkatan tersebut sektor pariwisata menduduki posisi ke 2 setelah minyak sawit mentah yang menduduki posisi pertama dalam menyumbang devisi neraga terbesar. Tren positif ini memberikan kontribusi positif karena berdampak pada perluasan lapangan kerja, peningkatan ekonomi masyarakat, memacu pembangunan daerah, terutama di daerah dengan ketersediaan potensi daya tarik wisata. Salah satunya daerah Kabupaten Kotawaringin Barat yang memiliki berbagai potensi pariwisata diantaranya Taman Nasioal Tanjung Puting (TNTP), Desa Wisata Kopi di Desa Kumpai Batu Atas, dan lain-lain. Sebelum dikembangkan desa wisata kopi, petani kopi di desa tersebut mengalami berbagai masalah dan kendala karena harga yang murah (20 ribu rupiah / kilo) dan akses yang minim terhadap pasar. Hal ini yang mengakibatkan kebanyakan masyarakat beralih ke komuditas lainnya. Akan tetapi pada tahun 2017 kopi mulai dikembangkan oleh komunitas local menuju desa wisata kopi sehingga harga mengalami peningkatan menjadi 300 ribu rupiah per kilo. Selain itu terjadi peningkatan pengunjung wisatawan mancanegara dan nusantara. penelitian ini bertujuan untuk mengetahui dan menganalisis peran Modal Sosial (bonding, bridging, networking) Kelompok Sadar Wisata (POKDARWIS) dalam mengembangkan desa wisata kopi di Desa Kumpai Batu Atas, Kabupaten Kotawaringin Barat. Penelitian ini menggunakan metodologi kualitatif deskriptif. Dengan menggunakan teknik snowball sampling dalam menentukan informan. Hasil penelitian menunjukan bahwa para pihak (stakehorders) mulai dari swasta, pemerintah, media, LSM dan lainnya telah memberikan perhatian untuk mengembangkan wisata kopi seperti memberikan bantuan, peralatan, keuangan, pelatihan dan pendampingan.

Antusias tersebut tidak diimbangi dengan fungsi dan peran dari Kelompok Sadar Wisata. Karena minim komunikasi antara anggota sehingga kelompok ini belum ada kegiatan. Walaupun demikian salah satu actor (anggota pokdarwis) berkomitmen untuk 
menggembangkan desa wisata kopi sehingga bisa terkenal dan memberikan dampak bagi para petani kopi di Desa Kumpai Batu Atas

Kata Kunci : Modal Sosial, Pariwisata, Kopi Liberika, Kelompok Sadar Wisata

\section{PENDAHULUAN}

Indonesia merupakan salah satu Negara tujuan wisata dunia yang memiliki berbagai jenis objek wisata yang tersebar dari Sabang sampai Merauke. Trip Advisor merilis 25 destinasi wisata terbaik pada tahun 2018 dan Indonesia masuk 10 besar destinasi Top dunia (Genpi.co, 2018). Selain itu perkembangan pariwisata di Indonesia menunjukan trend positif yang ditandai dengan peningkatan pemasukan terhadap devisa Negara yang mencapai USD 15 juta atau sebesar 203 Triliun (tribunneews.com, 2018). Dari peningkatan tersebut sektor pariwisata menduduki posisi kedua setelah minyak sawit mentah yang menduduki posisi pertama dalam menyumbang devisi negara terbesar.

Dengan capaian tersebut, Pemerintah pusat telah menargetkan pada tahun 2019 untuk wisatawan asing sebesar 20 juta kunjungan. Untuk merealisasinya, pemerintah pusat dan pemerintah daerah harus bersinergi untuk mengembangkan destinasi yang telah ada dan membuat destinasi baru agar dapat meningkatkan pengunjung dan peningkatakan devisa Negara, Pendapatan Asli Daerah dan peningkatan ekonomi masyarakat. Pariwisata dianggap penting dalam pembangunan ekonomi di Indonesia karena merupakan salah satu sektor yang pertumbuhannya cukup pesat. Tren positif ini memberikan kontribusi positif terhadap pendapatan berbasis valuta asing, memperluas lapangan kerja, dan memacu pembangunan daerah, terutama di daerah dengan ketersediaan potensi daya tarik wisata.

Kabupatan Kotawaringin Barat, Provinsi Kalimantan Tengah merupakan salah satu daerah di Indonesia yang memiliki destinasi wisata berskala Internasional yaitu Taman Nasional Tanjung Putting (TNTP). Awalnya TNTP merupakan Suaka Marga Satwa Tanjung Puting, gabungan Cagar Alam Sampit dan Suaka Margasatwa Kotawaringin, yang ditetapkan oleh pemerintah kolonial Belanda tahun 1936/1937 seluas 205.000 H Untuk perlindungan Orangutan (pongo pygmeus) dan Bekantan (Nasalis Larvatus). Ditetapkan sebagai Taman Nasional berdasarkan SK Kementrian kehutanan nomor 096/kpts11/84 tanggal 12 mei 1984 dan Berdasarkan surat keputusan Direktorat Jendral Perlindungan Hutan dan Pelestarian Alam Nomor 45/kpts/VI-sek/84 tanggal 11 Desember 1984 wilayah kerja TNTP ditetapkan meliputi areal suaka margasatwa tanjung puting dengan luas kawasan $300.040 \mathrm{H}$. Dengan keunikan tersebut sehingga TNTP saat ini telah diminati oleh wisatawan mancanegara (wisman) maupun wisatawan nusantara (wisnus). Berdasarkan data Jumlah wisatawan yang berkunjung ke TNTP dari tahun ke tahun menunjukkan tren positif. Berikut ini jumlah tabel pengunjung yang telah terdata berdasarkan data TNTP tahun 2018. 
Tabel 1. Data Pengunjung TNTP

\begin{tabular}{ccc}
\hline Tahun & $\begin{array}{c}\text { Wisatawan } \\
\text { Mancanegara }\end{array}$ & $\begin{array}{c}\text { Wisatawan } \\
\text { Nusantara }\end{array}$ \\
\hline 2012 & 7.727 Orang & 4.559 Orang \\
2013 & 8.439 Orang & 4.916 Orang \\
2014 & 10.986 Orang & 5.703 Orang \\
2015 & 9.767 Orang & 2.797 Orang \\
2016 & 8.927 Orang & 6.164 Orang \\
2017 & 15.163 Orang & 9.975 Orang \\
2018 & 18.837 Orang & 10.449 Orang \\
\hline
\end{tabular}

Sumber : Data diolah, 2019

Berdasarkan data Dinas Pariwisata (2016), di Kabupaten Kotawaringin Barat terdapat beberapa objek wisata, yaitu:

1. Wisata alam; Taman Nasional Tanjung Putting, Orangutan Care Center Quarantie (OCCQ), Pantai Kubu, Pantai Tanjung Keluang, Pantai Bogam, Pantai Keraya, Pantai Sabuai, Susur Sungai Arut, Pantai Tanjung Harapan, Taman Laut Senggora, Danau Gatal dan Danau Masaurayan.

2. Wisata budaya-Sejarah; Istana Kuning, Istana Alnursari, Istana Mangkubumi, Masjid Dan Makam Kyai Gede Dan Monument Palagan Samba.

3. Wisata desa adat; Desa Adat Pasir Panjang, Desa Adat Pandau, Riam Dan Panahan, Desa Adat Darat.

4. Agro wisata; Sawah Penati SP-1, Sawah Desa Barabai, Sulung Rach Dan Kebun Durian Montong.

Selain beberapa objek wisata yang telah dipaparkan diatas, Kabupaten Kotawaringin Barat memiliki objek wisata baru yaitu objek wisata yang berada didesa Kumpai Batu Atas yang dikembangkan oleh Kelompok Sadar Wisata dan Komunitas Lokal sejak bulan Oktober 2017 yakni Desa Wisata Kopi. Berdasarkan pra penelitian yang dilakukan oleh penulis pada awal tahun 2018 ditemukan bahwa sebelum pariwisata masuk kedesa Kumpai Batu Atas para petani mengalami kendala dan kesulitan dalam menjual kopi dan harga jual kopi yang sangat rendah. Hal ini yang akhirnya mengakibatkan sebagian besar masyarakat beralih ke komoditas lainnya. Sejak dikembangkan kembali tanaman kopi di Desa Kumpai Batu Atas, harga kopi dari waktu ke waktu mengalami peningkatan yang sebelumnya per kilo 25 ribu dan saat ini mencapai 40-60 ribu rupiah.

Dalam mengembangkan wisata Desa Kumpai Batu Atas tidak terlepas dari kerjasama dari Kelompok Sadar Wisata (pokdarwis) yang ada di desa tersebut. Pokdarwis telah bekerjasama dengan beberapa komunitas stakeholder yang ada di Kabupaten Kotawaringin Barat untuk mengadakan beberapa kegiatan seperti pelatihan dan pendampingan bagi petani kopi guna meningkatkan kesejahteraan petani. Jenis kopi yang dihasilkan oleh para petani adalah jenis 
kopi Liberika dan Robusta. Menurut pemberitahuan melalui media (borneonews.co.id, 2018) saat ini desa wisata kopi tersebut menjadi daya tarik untuk wisatawan asing dan nusantara

Berdasarkan uraian diatas maka tujuan dari penelitian ini untuk mendeskripsikan serta menganalisis Peran Modal Sosial Kelompok Sadar Wisata dalam Mengembangkan Desa Wisata Kopi di Desa Kumpai Batu Atas, Kabupaten Kotawaringin Barat, Provinsi Kalimantan Tengah?

\section{METODE PENELITIAN}

Secara umum terdapat dua metodologi penelitian yang sering digunakan oleh para peneliti yaitu Kuantitatif dan Kualitatif. Akan tetapi dalam penelitian ini penulis menggunakan pendekatan kualitatif. Menurut Rukajat (2018) kualitatif adalah jenis penelitian yang temuan-temuannya tidak diperoleh melalui prosedur kuantifikasi seperti perhitungan statistik atau bentuk cara-cara lainnya yang menggunakan angka.

Selain itu menurut Moleong (2012) Pendekatan kualitatif merupakan suatu pendekatan yang sifatnya hanya untuk mencari kesimpulan berdasarkan persoalan penelitian melalui hasil data deskriptif yang berupa kata-kata yang tertulis atau lisan, gambar dengan menggunakan teknik Observasi, wawancara dari orang-orang dan pelaku yang dapat diamati serta penelaahan dokumen.

Silalahi (2012) menambahkan kualitatif merupakan serangkaian data hasil observasi. Sehingga tujuan dari kualitatif menekankan pada cakupan informasi tentang fenomena utama yang dieksplorasi dalam penelitian, partisipan penelitian dan lokasi penelitian.

Dalam penelitian ini Jenis penelitian yang digunakan adalah deskriptif. Deskriptif mencoba memberikan gambaran keadaan masa sekarang secara mendalam. Menurut Nawawi (1992) Penelitian deskriptif dapat diartikan prosedur atau cara memecahkan masalah penelitian dengan memaparkan keadaan objek yang diselidiki sebagai mana adanya berdasarkan fakta-fakta yang aktual pada saat sekarang.

Selanjutnya oleh Sumanto (1990), penelitian deskriptif berkaitan erat dengan pengumpulan data untuk memberikan penegasan terhadap konsep atau gejala, juga menjawab pertanyaan-pertanyaan sehubungan dengan status subyek peneliti pada saat ini. misalnya sikap atau pendapat terhadap individu, organisasi dan sebagainnya. Menambahkan tulisan Nawawi dan Sumanto, Menurut Silalahi (2012), penelitian deskriptif selain bertujuan menggambarkan secara cermat karakteristik dari suatu gejala atau masalah yang diteliti, penelitian deskriptif juga fokus pada pertanyaan dasar "bagaimana" dengan berusaha mendapatkan dan menyampaikan fakta-fakta dengan jelas serta teliti.

Metode Analisis data yang digunakan terbagi kedalam beberapa bagian diantaranya 1) Reduksi data, 2) Penyajian Data dan 3) Penarikan Kesimpulan dan Verifikasi. 
Penelitian ini dilakuka di desa Kumpai Batas (KBA), Kecamatan Arut Selatan, Kabupaten Kotawaringin Barat, Kalimantan Tengah yang memiliki luas wilayah kurang lebih $30.000 \mathrm{~m}^{2}$. Berdasarkan buku desa pada tahun 2015 jumlah Kepala Keluarga (KK) sebanyak 934 dengan jumlah panduduk 2.976 jiwa. Untuk rincian penduduk berdasarkan jenis kelamin, Laki-laki berjumlah 1.582 jiwa dan perempuan berjumlah 1.394 jiwa. Desa ini memiliki beragam potensi. Salah satunya adalah kopi

\section{HASIL DAN PEMBAHASAN}

\section{Sejarah Masuknya Kopi di Desa Kumpai Batu Atas (KBA)}

Masuknya kopi di Desa Kumpai Batu Atas (KBA) dimulai sejak tahun 1986, yang diawali dengan program pemerintah yakni transmigrasi untukanggota masyarakat yang akan menempati pulau Kalimantan yakni di desa Kumpai Batu Atas, Kabupaten Kotawaringin Barat. Jenis kopi yang dibawa dari Jawa Timur adalah Liberika dan Robusta. Perbedaan kedua jenis kopi tersebut, terletak pada daun dan buah. Untuk jenis kopi liberika, daunnya besar/lebar dan buahnya besar. Sedangkan Robusta daunnya kasar, kecil dan buahnya kecil.

Seluruh masyarakat diberikan bibit kopi kedua jenis kopi tersebut untuk ditanam pada lokasi yang sudah disediakan oleh pemerintah daerah. berikut merupakan kutipan wawancara dengan bpk Sutrisno (beliau merupakan salah satu anggota Kelompok Sadar Wisata (Pokdarwis) sekaligus sebagai pemilik kebun kopi yang dijadikan lokasi wisata kopi dan ketua kelompok tani Buria Lestari)

Setelah dilakukan pembibitan oleh masyarakat, kemudian pada tahun 1996 mulai ditanam pada lokasi yang telah disediakan. Pada saat itu masyarakat hanya menanam untuk mengkonsumsi sendiri dan sebagian dijual ke pasar dengan harga 20-30ribu perkilogramnya. Saat dijual ke pasar, tidak semua kopi terjual habis. Berikut ini hasil wawancara dengan bapak Sutrisno: "jika dijual 10 kilogram, biasanya hanya laku 2-5 kilogram Sisahnya dikembalikan"

Selain itu karena masyarakat tidak memiliki keahlian dalam pemeliharaan dan perawatan mengakibatkan sejumlah pohon kopi mati dan terkena hama. Karena tidak menguntungkan bagi masyarakat, sebagian kebun kopi dialihfungsikan / ditebang pohon kopi dan diganti dengan tanaman lainnya seperti sayur-sayuran, buah-buahan. Kejadian seperti itu terjadi karena faktor ekonomi yakni kurang/minimnya keuntungan yang didapatkan oleh masyarakat (Anugerah, 2013). Selain itu, dengan adanya keterbatasan Sumber Daya Manusia (SDM) juga mempengaruhi tingkat pengetahuan dan keterampilan (Suradisastra dkk, 2014) dalam pengembangan, kreativitas dan inovasi untuk menciptakan produk dari bahan dasar kopi. untuk menciptakan SDM yang unggul diperlukan wadah bagi masyarakat perdesaan untuk belajar secara non formal sehingga dapat meningkatkan kreatifitas dan inovasi agar 
dapat menciptakan diversifikasi prodak demi meningkatkan ekonomi keluarga. Selain itu karena telah dialih fungsi lahan, Berdasarkan beberapa sumber dari media online (kumparan, borneonews) saat ini hanya tersisah 32 lokasi pekarangan kopi di rumah warga.

\section{Pengembangan Kopi di Desa Kumpai Batu Atas}

Pengembangan Kopi di Desa Kumpai Batu Atas tidak bisa lepas dari peran dan dukungan dari komunitas local yaitu Selanting (Seruyan Lamandau dan Tanjung Puting) dan KAHAWA (Brand Lokal). Dalam mengembangan kopi liberika, komunitas ini melakukan beberapa kegiatan seperti Identifikasi Potensi Kopi dan permasalahannya, Pendampingan/Pelatihan, Promosi, Pembentukan Kelompok Sadar Wisata, dan lain sebagainya.

\section{Identifikasi Potensi Kopi dan Masalah}

Saat ini banyak sekali desa-desa di Indonesia mengalami berbagai permasalahan diantaranya pengangguran dan kemiskinan. sedangkan banyak potensi namun belum dikelola dengan maksimal (Setyobakti, 2017). Hal serupa juga dialami oleh petani kopi yang berada di Desa Kumpai Batu Atas, Kabupaten Kotawaringin Barat. Dimana para petani belum memaksimalkan potensi yang dimiliki sehingga belum memberikan kontribusi bagi peningkatan ekonomi keluarga. Sedangkan pohon kopi telah dimiliki oleh masyarakat ada sejak tahun 1986.

Dengan adanya kondisi tersebut, komunitas selanting melakukan identifikasi potensi kopi dan permasalahan yang dialami oleh petani kopi di Desa Kumpai Batu Atas pada pertengahan tahun 2017. Beberapa petani mengatakan bahwa Permasalahan yang mereka alami selama ini adalah belum tersediannya pangsa pasar sehingga produk kopi yang telah mereka hasilkan tidak terjual habis. Setelah permasalahan ini teridentifikasi oleh komunitas Selanting. selanjutnya diadakan pendampingan petani kopi.

\section{Pelatihan Pupuk Organik}

Salah satu poin di_dalam pembangunan pariwisata adalah keberlanjutan lingkungan. Maka dari itu dalam mengembangkan desa wisata kopi adalah dengan cara menggunakan pupuk organik. Menurut Hartatik (2015) pupuk organik sebagai alternative pelestarian lingkungan karena tidak menggunakan pupuk kimia/pestisida. Selain itu dapat meningkatkan kesuburan tanah (Roidah, 2013). Untuk tetap menjaga keberlanjutan lingkungan, diawal tahun 2018 Komunitas Selanting mengadakan beberapa kali kegiatan pelatihan pembuatan pupuk organic dengan petani kopi di Desa Kumpai Batu Atas yang diadakan dibelakang rumah bapak Sutrisno. Dengan menggunakan pupuk organik sebagai penciri, diharapkan dapat meningkatkan produktifitas kopi 
serta berdampak bagi pengunjung wisatawan mancanegara maupun nusantara untuk melihat dan merasakan kopi dengan menggunakan pupuk organik.

\section{Pengembangan Produk Lokal}

Pengembangan produk local merupakan salah satu cara untuk meningkatkan penjualan ke pangsa pasar (Rini, 2013). Menurut Kotler dan Keller (2019) terdapa 8 tahapan dalam mengembangkan produk local diantaranya 1) Penciptaan Ide, 2) Penyaringan Ide, 3) Pengembangan dan Pengujian Konsep Ide yang menarik harus disempurnakan menjadi konsep produk yang dapat diuji, 4) Pengembangan Strategi Pemasaran, 5) Analisis Bisnis, 6) Pengembangan Produk, 7) Pengujian Pasar, 8) Tahap Komersialisasi. Untuk mengembangkan produk local kopi Liberika di desa Kumpai Batu Atas, Komunitas Selanting mengadakan pelatihan bagi para petani kopi di tahun 2017 dan diikuti oleh Bapak Sutrisno dan Bapak Sauji. Walaupun hanya diikuti oleh dua orang, pelatihan tetap dilakukan dan menghasilkan brand kopi. Para petani diberikan kebebasan dalam mengekspresikan ide untuk membuat brand/logo. Setelah kopi mulai dikenal pada tahun 2018 perkembangan kopi di desa Kumpai Batu Atas mengalami peningkatan yang sangat pesat yang ditandai dengan banyaknya permintaan dan meningkatnya jumlah wisatawan mancanegara dan nusantara. Dengan perkembangan tersebut, bapak Sutrisno dibantu oleh anggota Selanting dan mahasiswa dari Universitas Antakusuma mengembangkan dan melakukan diversifikasi produk kopi yaitu dengan kemasan yang lebih kecil/ekonomis. Hal tersebut dilakukan karena adanya masukan dari pengunjung mengenai harga (dalam kemasan besar) yang dirasa terlalu mahal. Berdasarkan masukan itulah sehingga dibuat kembali kemasan dalam bentuk sasetan dengan harga yang lebih ekonomis bagi para pengunjung sebagai oleh-oleh kopi dari desa Kumpai Batu Atas. Produk kopi tersebut selain dijual dirumah bapak sutrisno, selain tiu dipasarkan ke berbagai kafe di Pangkalan Bun dan diluar daerah seperti Kabupaten Lamandau, Kota Palangkaraya dan Jakarta. Dengan adanya peningkatan permintaan dan penjualan produk kopi diharapkan dapat meningkatkan ekonomi keluarga.

\section{Penyusunan Paket Wisata}

Salah satu kegiatan program dari komunitas Selanting untuk mengembangkan kopi Liberika di Desa Kumpai Batu Atas yaitu menyusun paket wisata kopi agar para tour operator memiliki acauan dan pedoman. dalam penyusunan paket wisata kopi, dihadiri oleh guide dari Taman Nasional Tanjung Puting yaitu Mba Rini dan Mba Nina serta petani kopi dalam penyunan paket wista, telah disepaki oleh berbagai pihak mengenai harga seperti (setangah hari) half day dan full day (satu hari) bagi wisatawan mancanegara maupun nusantara. Berikut ini rincian paket wisata kopi desa Kumpai Batu Atas. Setelah dibuat paket tersebut, guide tanaman nasional tanjung putting beberapa kali 
membawa tamu dari Eropa dan Asia untuk melihat proses pembuatan kopi dengan cara tradisional.

Karena pesatnya pengembangan wisata kopi Liberika di desa kumpai batu atas, selanting berinisiatif untuk membentuk Kelompok Sadar Wisata (Pokdarwis) agar bisa mengelola potensi kopi yang telah dikembangkan oleh komunitas Selanting demi kesejahteraan masyarakat dan keberlanjutan lingkungan sekitar

\section{Pembentukan Kelompok Sadar Wisata (Pokdarwis)}

Kelompok Sadar Wisata (Pokdarwis) merupakan organisasi atau kelembagaan secara formal di tingkat desa untuk mengembangkan pariwisata dengan tujuan meningkatkan partisipasi masyarakat secara keseluruhan (Wardhani, 2016), agar dapat meningkatkan ekonomi secara keseluruhan. Selain itu terbentuknya suatu organisasi pokdarwis di tingkat desa, merupakan bagian dari dukungan terhapat pemerintah dengan tujuan agar pariwisata dapat dikelola dengan baik.

Terbentuknya Kelompok Sadar Wisata (POKDARWIS) di desa Kumpai Batu Atas (KBA) diinisiasi oleh komunitas SELANTING yang dilakukan pada bulan February 2018. Proses pembentukan pokdarwis diadakan di kantor desa Kumpai Batu Atas (KBA). dalam kegiatan tersebut dihadiri oleh perwakilan dari Dinas Pariwisata Kabupaten Kotawaringin Barat, kepala desa dan perangkat desa Kumpai Batu Atas, Tokoh Masyarakat, Pemuda dan masyarakat.

Peran komunitas (eksernal) sengat penting untuk mengubah pola pikir dan mendorong masyarakat agar membentuk kelembagaan local (kelompok sadar wisata) sehingga bisa mengatur dan mengelola potensi yang dimiliki. Hal serupa juga dilakukan oleh Komunitas Salam Rawa untuk mengembangkan desa wisata Dewi Sari dan membentuk Pokdarwis (Wardhani, 2016).

Setelah disepakati bersama-sama struktur organisasi Pokdarwis di Desa Kumpai Batu Atas selanjutnya diserahkan kepada Dinas Pariwisata Kabupaten Kotawaringin Barat untuk ditindak lanjuti. Berselang beberapa hari setelah pembentukan pokdarwis, dinas pariwisata mengeluarkan SK Nomor: 556/04/Dispar-I tentangPembentukan Kelompok Sadarwisata (Pokdarwis) Sekar Wangi Desa Kumpai Batu Atas. Berikut ini merupakan struktur organisasi Pokdarwis. Dari tabel diatas dapat dijelaskan bahwa posisi penasehat adalah bapak Sarianto yang merupakan kepala desa Kumpai Batu Atas. Ketua diisi oleh bpk Sauji yang merupakan salah satu petani kopi. Dibawanya ada wakil sekretaris dan bendahara. Dalam kelompok sadar wisata memiliki empat seksi yang dibantu oleh enam anggota. Setelah dikeluarkan SK Pokdarwis desa Kumpai Batu Atas belum menunjukan eksistensinya / aktifitas dalam mengembangkan desa wisata kopi. Selain itu minimnya pengetahuan dan informasi mengenai peran dan fungsi pokdarwisa sehingga belum adanya 
kegiatan. Walaupun demikian para anggota sering mengikuti kegiatan yang diadakan oleh Dinas Parwisata untuk mengembangkan pariwisata.

\section{Peran Para Pihak}

Setelah kelompok sadar wisata (pokdarwis) terbentuk dan kopi liberika dan robusta mulai dikenal oleh masyarakat umum, para pihak/stakeholders mulai berdatangan untuk memberikan dukungan baik secara fisik non fisik bagi pengembangan kopi di Desa Kumpai Batu Atas. Para pihak itu diantaranya

1. Pemerintah Pusat dan Daerah

2. Perbankan

3. Perguruan Tinggi dan Sekolah Menengah Kejuruan

4. Cafe dan Kedai Kopi

5. Tour Operator

Para pihak diatas sampai saat ini (2019) masih mendukung pengembangan kopi di Desa Kumpai Batu Atas. Hanya saja Kelompok Sadar Wisata belum memaksimalkan para pihak yang telah datang untuk mengembangkan kopi. sampai saat ini hanya Bpk Sutris yang masih konsisten/berkominten bersama-sama dengan para pihak

\section{Modal Sosial}

Keberhasilan dalam berbagai aspek pembangunan salah satunya ditentukan oleh modal sosial (Kimbal, 2015). Menurut Rustiadi (2011) modal sosial memiliki 3 komponen utama diantara : Kepercayaan (trush), Jejaring (linking) dan norma (norms). Dalam mengembangkan kopi di desa kumpai Batu Atas (KBA) Kabupaten Kotawaringin Barat, telah ditemukan alur seperti dibawah ini.

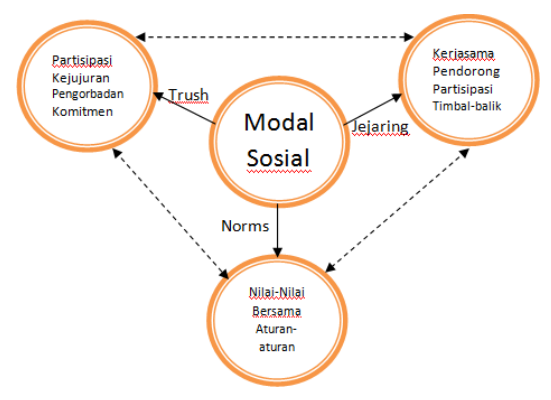

Gambar 1

Konsep modal sosial dikembangkan dari Rustiadi (2011) disesuaikan dalam temuan lapangan.

Berdasarkan alur diatas dapat dijelaskan bahwa dalam mengembangkan desa wisata kopi di desa kumpai batu atas, dimulai dari peran jejaring sebagai mendorong untuk pengembangan produk dan pembentukan sebuah institusi/organisasi kepariwisataan atau dengan istilah kelompok sadar wisata 
(Pokdarwis). Menurut Mubyarto dalam Syahriar (2015) organisasi yang terbentuk baik formal maupun informal pada prinsipnya adalah mengatur setiap tindakan anggota dalam kegiatan untuk mencapai tujuan tertentu.

Terbentunya kelembagaan tersebut tidak bisa lepas dari peran jejaring seperti peran sector swasta, pemerintah dan perorangan. Ciptosari (2019) mengemukakan bahwa peran jejaring (linking socialcapital) merupakan salah satu unsur penting dalam mengembangkan sarta mendukung kegiatan atau program dalam rangka transfer of knowledge seperti mengadakan pelatihan dan pendampingan, pemberian alat-alat, financial serta lain sebagainya. Bantuan yang didapatkan baik berupa kegiatan oleh pihak swasta dan pemerintah serta juga bantuan paralatan dan anggaran untuk menanam bibit kopi.

Setelah kopi Liberika mulai terkenal, telah berdatangan para pihak untuk berpartisipasi seperti 1) permintaan kopi dari penjual kopi wilayah Pangkalan Bun dan luar Pangkalan Bun, 2). Bank Indonesia Wilayah Provinsi Kalimantan Tengah memberikan bantuan pembiayaan pembibitan, 3) Anggota DPR RI wilayah Kalimantan Tengah memberikan bantuan peralatan. 4) tempat prakter mahasiswa Universitas Antakusuma, Politeknik dan SMKN 2 Pangkalan Bun. Selain itu masih terdapat beberapa peran Pemerintah dan Swasta dalam mengembangkan kopi di Desa Kumpai Batu Atas . Dengan adanya partisipasi dan kerja sama tersebut terdapat timbal balik yang dihasilkan baik dalam transaksi jual beli secara finansial dari kedua belah pihak maupun dari lembaga pendidikan, pemerintah dan swasta mendapatkan feedback dari kegiatan tersebut.

Dengan banyaknya jejaring dan keterlibatan para pihak untuk mengembangkan dan membeli kopi, tidak sejalan dengan partisipasi keanggotaan di dalam kelompok sadar wisata dalam mengembangkan kopi di desa kumpai batu atas. Hal tersebut diakibatkan dari minimnya koornidasi dan komunikasi antara anggota sehingga mengakibatkan organisasi ini belum memiliki program untuk mengembangkan desa wisata kopi. Hal serupa juga terjadi pada Pada Obyek Wisata Colo Kabupaten Kudus. Menurut Syahriar (2015) Karena minimnya interaksi antar stakeholders yang berkepentingan sehingga saling menyalahkan atas kewenangan dan tanggung jawab pihakpihak tersebut sehingga pengembangan pariwisata cenderung lambat.

Hal yang berbeda terjadi pada Kelompok Sadar Wisata (Pokdarwis) yaitu bukan pada minimnya interaksi antar shakeholdes melainkan minimnya interaksi antar anggota kelompok dalam organisasi. Berdasarkan hasil penelitian menunjukan bahwa interakhir pihak luar (stakeholders) dengan petani kopi dalam mengembangkan kopi di desa kumpai batu atas berjalan dengan baik. walaupun demikian tidak mengurangi semangat salah satu anggota kelompok pokdarwis yaitu bpk sutristo dalam mengembangkan kopi di desa Kumpai Batu Atas. 
Kepercayaan yang dibangun untuk mengembangkan kopi diantaranya : para petani kopi memberikan kepercayaan kepada pak sutrisno untuk memanen kopi dikebun mereka. Hungan antara para petani begitu baik. Selain itu terbangunnya kepercayaan antara pak sutrisno dengan shakehorders, dapat dilihat dari kegiatan dan dukungan secara fisik maupun nonfisik

\section{SIMPULAN DAN SARAN}

\section{Simpulan}

Desa Kumpai Batu Atas (KBA) memiliki beragam potensi yang bisa dikembangkan untuk meningkatkan ekonomi masyarakat salah satunya adalah kopi. Karena keterbatasan sumber daya manusia (SDA) sehingga kopi tidak berkembang. Setelah berbagai komunitas local mengadakan penjajakan awal mulai dari identifikasi potensi, pelatihan dan pendampaingan serta mempromosikan, keberadaan kopi mulai diminati dan mendapatkan berbagai dukungan dari berbagai pihak seperti Pemerintah Pusat dan Daerah, Perbankan, Perguruan Tinggi dan Sekolah Menengah Kejuruan, Penjual Kopi dan Tour Operator.

Setelah dibentuknya kelompok sadar wisata (Pokdarwis) pada tahun 2018 awal, keberadaan organisasi ini belum menunjukan eksistensinya karena belum ada kegiatan dan program untuk mengembangkan wisata di Desa Kumpai Batu Atas. Walaupun demikian usaha untuk mengembangkan kopi dan menuju ke wisata kopi telah diwujudkan oleh peran para pihak dan semangat salah satu anggota kelompok sadar wisata yaitu bpk sutrisno yang selalu berkomitnen untuk mengembangkan kopi. para stakehorders sampai saat terus memberikan dukungan baik berupa peralatan, pelatihan, pendampingan, keuangan sehingga terbangun sebuah jejaring dan kepercayaan diantara mereka. Hal serupa juga terjadi antara anggota kelompok dimana bpk sutrino diberikan kepercayaan untuk memanen kopi dikebun para petani sehingga ini menjadi perekat dan berdampak pada kepercayaan. Peran pak sutrisno sebagai (aktor) juga selalu memberikan pemahaman kepada para petani kopi untuk mengembangkan kopi. hanya saja kesadaran itu belum Nampak dikarenakan komuditas ini bukan merupakan panghasilan utama bagi masyarakat secara umum di desa Kumpai Batu Atas. Hal ini yang mengakibatkan pemerataan ekonomi khususnya (kopi) belum diasakan oleh masyarakat umum. Sehingga hanya bpk sutrisno yang mendapatkan keuntungan secara financial.

\section{Saran}

Perlu dukungan pemerintah daerah khususnya Kabupaten Kotawaringin Barat agar melakukan pendampingan kepada kelompok sadar wisata yang telah terbentuk pada tahun 2018. Pendampingan secara berkelanjutan mulai dari perencanaan sampai tahapan evaluasi demi perkembangan dan kemajuan 
pariwisata di desa sehingga sampai saatnya masyarakat dapat mendiri untuk mengembangkan wisata dan tentunya dapat memberikan kontribusi bagi peningkatan ekonomi masyarakat dan Pendapatan Asli Daerah

\section{DAFTAR PUSTAKA}

Anugerah, I.W. 2013. Asean Free Trade Area (AFTA), Otonomi Daerah dan Daya Saing Perdagandan Komoditas Pertanian Indonesia. Forum Penelitian Agro Ekonomi. 21(1):1-11.

Bornenews. 2018. Desa Kumpai Batu Atas Dikunjungi 320 Wisata Asing dan Lokal. https://www.borneonews.co.id/berita/108097-desa-kumpaibatu-atas-dikunjungi-320-wisata-asing-dan-lokal

Bourdieu, Pierre.(1986). The form ofcapital. www.faculty.georgetown.edu /irvinem/theory/Bourdieu-FormsofCapital.pdf

Ciptosari, Fitri., Titi Prabawa dan Antonius Bele. 2019. Social Capital Dalam

Kewirausahaan Lokal, Kajian Keterlibatan Masyarakat Dalam Pariwisata

Di Delha, Kab. Rote Ndao, Nusa Tenggara Timur. Jurnal Kawistara. 9(1):45-59.

Dinas Pariwisata Kabupaten Kotawaringin Barat. 2016. Pariwisata Kotawaringin Barat: Sebuah Buku Panduan. Pangkalan Bun

Hartatik, W., Husnain dan Widowati, L.R. 2015. Peranan Pupuk Organik Dalam Peningkatan Produktivitas Tanah Dan Tanaman. Jurnal Sumberdaya Lahan.9(2):107-120.

Kimbal, R.W. 2015. Modal Sosial Dan Ekonomi Industri Kecil Sebuah Studi Kualitatif. Penerbit : Depublish, Yogyakarta.

Kotler, P \& Keller, K.L. 2009. Manajemen Pemasaran. Edisi 13, Jilid 1 dan 2, ErlanggaL: Jakarta.

Moleong, Lexy J. 2001. Metodologi Penelitian Kualitatif. Rosda Karya. Bandung

Nawawi, H. 1992. Instrumen Penelitian Bidang Sosial. Gadjah Mada University Publicarions. California.

Rini, E.S. 2013. Peran Pengembangan Produk Dalam Meningkatkan Penjualan. Jurnal Ekonom. 16(1):30-38.

Roidah, I.S. 2013. Manfaat Penggunaan Pupuk Organik Untuk Kesuburan Tanah. Jurnal Universitas Tulungagung BONOROWO. 1(1):30-42.

Rukajat, A. 2018. Pendekatan Penelitian Kualitatif (Qualitative Reseaarch Approach). Deepublish: Sleman.

Setyobakti, Moh H. 2017. Identifikasi Masalah dan Potensi Desa Berbasis Indek Desa Membangun (Idm) di Desa Gondowangi Kecamatan Wagir Kabupaten Malang. WIGA: Jurnal Penelitian Ilmu Ekonomi. 7(1): 1-14.

Silalahi, Ulber. 2012. Metode Penelitian Sosial. PT Refika Aditama. Bandung Sumanto. 1990. Metodologi Penelitian Sosial dan Pendidikan. Andi Offset. Yogyakarta 
Suradisastra, K., Suherman \& Dariah, A. 2014. Inovasi Kreatif Untuk Membangun Daya Saing Komoditas Pertanian. Jakarta: IAARD Press.

Syahriar, G.H. 2015. Modal Sosial Dalam Pengelolaan Dan Pengembangan Pariwisata Di Obyek Wisata Colo Kabupaten Kudus. Skripsi.

Tribunnews. 2018. Pariwisata penyumbang devisa kedua. https://www.tribunnews.com/nasional/2018/05/01/pariwisata penyumbang-devisa-kedua

TripAdvisor. 2018. Rilis 10 Tempat Wisata Terbaik di Dunia, Bali Urutan Kelima. https://www.genpi.co/berita/8384/tripadvisor-rilis-10-tempat-wisataterbaik-di-dunia-bali-urutan-kelima?page $=2$

Wahyudi, E. 2010. Strategi Peningkatan Akses Pasar dan Peluang Inovasi Usaha Kecil Nelayan Pasuruan.

http://www.journal.unair.ac.id/filerPDF/04_edit\%20final\%20fix\%20edy_STRA TEGI\%20edited\%20mita.pdf

Wardhani, A.A. 2016. Peran Pokdarwis dalam pengebangan desa wisata dewi sri. Program Studi Destinasi Pariwisata Fakultas Teknologi Informasi. Universitas Satya Wacana. Salatiga. 